\title{
EFFECT OF INDOMETHACIN ON BLOOD PLASMA LEVELS OF LH AND TESTOSTERONE IN MALE RATS*
}

\author{
S. K. SAKSENA, $\uparrow$ I. F. LAU, A. BARTKE AND M. C. CHANG \\ Worcester Foundation for Experimental Biology, \\ Shrewsbury, Massachusetts 01545, U.S.A.
}

(Received 4th Fuly 1974)

\begin{abstract}
Summary. Treatment of adult male rats with indomethacin, an inhibitor of prostaglandin (PG) synthesis, caused a significant decrease in $\mathrm{LH}$ and testosterone levels in the blood plasma and in the weight of the seminal vesicles, but the weight of the testes and ventral prostate, the levels of FSH in the plasma and fertility were not affected. The concentration of PGF in the blood plasma of the treated animals was reduced, even though measurable amounts of PGs were present in every group. The results of this study, together with the known effects of PG administration on LH release, suggest that the reduction of plasma LH levels in rats injected with indomethacin was due to decreased PG synthesis. It appears that PGs are normally involved in the regulation of $\mathrm{LH}$ release.
\end{abstract}

\section{INTRODUCTION}

The physiological function of prostaglandins (PGs) in the male reproductive system is obscure and there is no clear-cut relationship between the content of PGs in the semen and fertility in men. Altered concentrations of prostaglandin E (PGE) and prostaglandin F (PGF) in the seminal plasma were recorded, however, in a number of men with unexplained sterility (Bygdeman, Fredricsson, Svanbörg \& Samuelsson, 1970; Brummer \& Gillespie, 1972; E. L. Klaiber, H. M. Constantian, T. B. Pokoly, W. A. Stylos and A. Bartke, unpublished data). The motility of human spermatozoa in cervical mucus in vitro was increased by PGF $_{2 \alpha}$ (Eskin, Azarbal, Sepic \& Slate, 1973). In rats, PGs are present in the testis, epididymis, ductus deferens and accessory reproductive glands (Carpenter, Manning \& Wiseman, 1971; Tan \& Privett, 1972; A. Bartke and S. Koerner, unpublished data) as well as in the peripheral plasma (Barcikowski, Saksena \& Bartke, 1973), and a physiological rôle of PGs in testis function has been suggested (Hargrove, Johnson \& Ellis, 1971). Administration of high doses of various PGs was observed to decrease plasma testosterone levels in mice, rats and hamsters (Bartke, Musto, Caldwell \&

* Reprint requests to Dr M. C. Chang.

$\dagger$ Present address: Reproductive Endocrinology Research Unit, Karolinska Sjukhuset 10401, Stockholm 60, Sweden. 
Behrman, 1973; Saksena, El Safoury \& Bartke, 1973; Lubicz-Nawrocki, Saksena \& Chang, 1973; Saksena, Lau \& Bartke, 1974) and to reduce spermatogenesis and the weight of accessory glands in rats (Ericsson, 1973). These observations suggest that changing the endogenous levels of PGs could interfere with male fertility.

The present work was undertaken to study the effects of the chronic treatment of male rats with indomethacin, an inhibitor of PG synthesis, on the plasma levels of LH, FSH and testosterone and on fertility. The weights of the testes and the accessory glands and the concentrations of PGE and PGF in the plasma of rats treated with indomethacin were also examined.

\section{MATERIALS AND METHODS}

Fertile male CD rats purchased from Charles River Breeding Laboratories and weighing between 400 and $450 \mathrm{~g}$ were randomly assigned to various treatment groups, using six or seven animals per group. The rats were injected subcutaneously with $1.0,1.5,2.5$ or $4.0 \mathrm{mg}$ indomethacin in $0.2 \mathrm{ml}$ peanut oil, or with $0.2 \mathrm{ml}$ peanut oil alone, daily for 30 days. On the 15 th and on the 30th day of treatment, each male was placed overnight with a pro-oestrous female. The females were examined on the following morning for the presence of spermatozoa in the vagina. The mated females were killed on the next day between 14.00 and 16.00 hours, i.e. 36 to $40 \mathrm{hr}$ after mating, and oviducal flushings were examined for the presence of two-cell ova. The males were anaesthetized with sodium pentobarbitone $24 \mathrm{hr}$ after the last indomethacin injection, and blood was collected from the abdominal aorta with a heparinized syringe. After centrifugation at $4^{\circ} \mathrm{C}$, the plasma was frozen and stored at $-20^{\circ} \mathrm{C}$ for the assays of LH, FSH, testosterone, PGE and PGF. The weights of the testes, the ventral prostate, and the seminal vesicles (together with their secretions) were also recorded.

Assay of PGE and PGF. Plasma $(1 \mathrm{ml})$ and $2 \mathrm{ml}$ acetate buffer $(\mathrm{pH} 4.5)$ together with tracers (approximately $1500 \mathrm{~d} / \mathrm{min}$ of $\left[{ }^{3} \mathrm{H}\right] \mathrm{PGE}_{2}$ and $1500 \mathrm{~d} / \mathrm{min}$ of $\left.\left[{ }^{3} \mathrm{H}\right] \mathrm{PGF}_{2 \alpha}\right)$ were extracted twice with 3 vols of a mixture of ethyl acetate and cyclohexane $(2: 1, \mathrm{v} / \mathrm{v})$. The pooled extracts were washed with $5 \mathrm{ml}$ distilled water, dried under nitrogen and chromatographed as described by Saksena, Watson, Lau \& Shaikh (1974). The concentrations of PGE and PGF were measured by radioimmunoassay (Stylos, Burstein, Rivetz, Gunsalus \& Skarnes, 1972; Stylos, Howard, Ritzi \& Skarnes, 1974). The antiserum used in the PGF assay gave a cross-reaction of nearly $100 \%$ with $\mathrm{PGF}_{1 \alpha}$, but did not cross-react with $\mathrm{PGE}_{1}, \mathrm{PGE}_{2}, \mathrm{PGA}, 13,14$-dihydro-PGF $\mathrm{P}_{2 \alpha}$, or 13,14dihydro-15-keto- $\mathrm{PGF}_{2 \alpha}$ when these substances were added in amounts up to $10 \mathrm{ng}$. The antiserum used in the PGE assay gave a cross-reaction of approximately $25 \%$ with $\mathrm{PGE}_{2}$ (at the point of $50 \%$ binding) but not with prostaglandins $A_{1}, A_{2}, B_{1}, B_{2}, F_{1 \alpha}$ or $F_{2 \alpha}$, or with 13,14-dihydro-PGE ${ }_{1}$ and $P_{G E}$, and 13,14-dihydro-15-keto-PGE $\mathrm{F}_{1}$ and $\mathrm{E}_{2}$ (again in amounts up to $10 \mathrm{ng}$ ). Prostaglandins $F_{2 \alpha}$ and $E_{1}$ were used as standards in these assays. Since PGEs and PGFs were not distinguishable within their groups, the results were expressed as total PGE and PGF concentrations. The recovery of tracers 
ranged from 70 to $80 \%$, the water blanks were below $50 \mathrm{pg}$, the sensitivity was approximately $25 \mathrm{pg}$ PGE and $50 \mathrm{pg}$ PGF, and the intra-assay coefficient of variation was $10 \%$.

Assay of LH and FSH. Plasma LH and FSH were determined using postprecipitation double antibody radioimmunoassays, which were modifications of the procedures described by Niswender, Midgley, Monroe \& Reichert (1968) and by Gay, Niswender, Midgley \& Reichert (1970). Plasma FSH was assayed using the NIAMD rat FSH radioimmunoassay kit. The procedure for FSH assay was identical to that for LH except that iodination was accomplished with $1 \mathrm{mCi}{ }^{125} \mathrm{I} / 2.5 \mu \mathrm{g}$ antigen and exposure to chloramine $\mathrm{T}$ was for $45 \mathrm{sec}$ instead of $60 \mathrm{sec}$. The sensitivities of the assays for LH and FSH were 0.5 and $5 \mathrm{ng}$, respectively, and the intra-assay coefficient of variation was $10 \%$.

Assay of testosterone. The concentrations of testosterone in the plasma were determined by radioimmunoassay after separation of the testosterone fraction on Sephadex LH-20 columns using 2,2,4-trimethylpentane : methanol : benzene $(90: 5: 5$, by vol.) as a solvent system (Bartke, Steele, Musto \& Caldwell, 1973). The antiserum used in this assay was raised in a rabbit injected with testosterone-3-BSA conjugate and gave a cross-reaction of $100 \%$ with dihydrotestosterone. Dihydrotestosterone was separated from testosterone on Sephadex LH-20 columns. The values of the water blank were below $10 \mathrm{pg}$ testosterone, the sensitivity was approximately $40 \mathrm{pg}$ testosterone and the intraassay coefficient of variation was $9 \%$.

The significance of differences between various groups was determined by the analysis of variance and Duncan's test.

\section{RESULTS}

The concentration of $\mathrm{LH}$ and testosterone in the plasma of rats treated with indomethacin and the results of fertility tests are given in Table 1. Administration of $4.0 \mathrm{mg}$ indomethacin/day was lethal to all rats within 5 days. Treatment with $1.0,1.5$ or $2.5 \mathrm{mg}$ indomethacin/day caused a significant reduction in the concentration of $\mathrm{LH}$ and testosterone in the plasma. These effects were not related to the dose. Plasma FSH levels appeared reduced in the treated rats, but the differences from the control group were not significant. All the rats mated after 15 and 30 days of treatment with indomethacin, and their fertility was apparently not affected. The number of two-cell ova flushed from the oviducts of females mated to control and to treated males did not differ.

The weights of the testes and the ventral prostate were not affected but the weight of the seminal vesicles was significantly reduced in the animals treated with indomethacin (Table 2). This effect was more pronounced in the animals given higher doses.

The concentration of PGE and PGF in the plasma of rats given different doses of indomethacin did not differ (Table 2) and, therefore, all groups were pooled for statistical comparisons. The concentration of PGF in the plasma (Mean \pm S.E.) was significantly reduced in treated animals $(0.45 \pm 0.04$ versus 


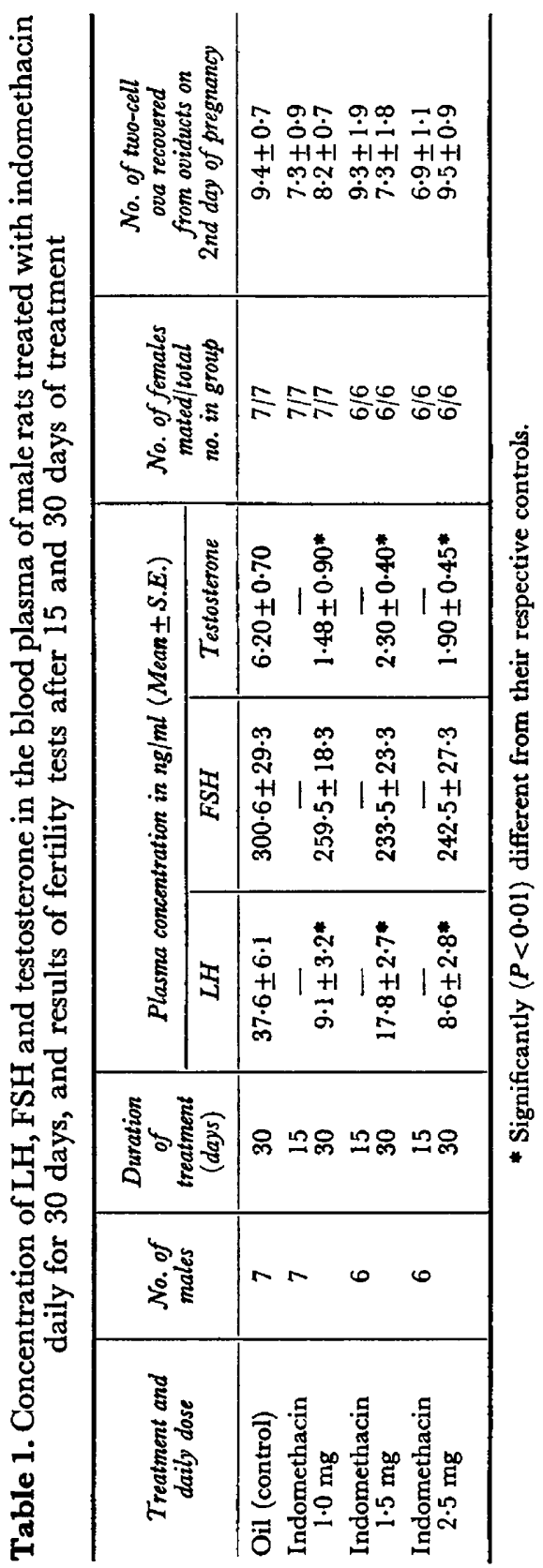


Table 2. The weight of the testes, seminal vesicles and ventral prostate and blood plasma concentrations of PGE and PGF in rats treated daily for 30 days with indomethacin

\begin{tabular}{|c|c|c|c|c|c|c|}
\hline \multirow{2}{*}{$\begin{array}{l}\text { Treatment and } \\
\text { daily dose }\end{array}$} & \multirow{2}{*}{$\begin{array}{l}\text { No. of } \\
\text { rats }\end{array}$} & \multicolumn{3}{|c|}{ Weight of organ (mg/100 g body wt) } & \multicolumn{2}{|c|}{$\begin{array}{c}\text { Blood plasma } \\
\text { concentration (ng/ml) }\end{array}$} \\
\hline & & Testes & $\begin{array}{c}\text { Ventral } \\
\text { prostate }\end{array}$ & $\begin{array}{c}\text { Seminal } \\
\text { vesicle }\end{array}$ & $P G E$ & $P G F$ \\
\hline $\begin{array}{l}\text { Oil (controls) } \\
\text { Indomethacin, } 1.0 \mathrm{mg} \\
\text { Indomethacin, } 1.5 \mathrm{mg} \\
\text { Indomethacin, } 2.5 \mathrm{mg}\end{array}$ & $\begin{array}{l}7 \\
7 \\
6 \\
6\end{array}$ & $\begin{array}{l}737 \pm 41 \\
762 \pm 38 \\
667 \pm 16 \\
633 \pm 85\end{array}$ & $\begin{array}{l}126 \pm 8 \\
103 \pm 7 \\
104 \pm 8 \\
119 \pm 6\end{array}$ & $\begin{array}{l}536 \pm 64 \\
303 \pm 15^{*} \\
228 \pm 10^{* *} \\
120 \pm 7^{* *}\end{array}$ & $\begin{array}{l}0.20 \pm 0.03 \\
0 \cdot 12 \pm 0.01 \\
0 \cdot 18 \pm 0.05 \\
0.15 \pm 0.03\end{array}$ & $\begin{array}{l}0.73 \pm 0 \cdot 14 \\
0 \cdot 46 \pm 0 \cdot 06^{* *} \\
0 \cdot 38 \pm 0 \cdot 07^{* *} \\
0 \cdot 54 \pm 0 \cdot 10^{*}\end{array}$ \\
\hline
\end{tabular}

Values are Means \pm S.E.

* Significantly $(P<0.05)$ different from their respective controls.

** Significantly $(P<0.01)$ different from their respective controls.

$0.73 \pm 0.14 \mathrm{ng} / \mathrm{ml} ; t=3.05 ; P<0.01)$. The concentration of PGE was apparently also decreased $(0.15 \pm 0.02$ versus $0.20 \pm 0.03 \mathrm{ng} / \mathrm{ml})$ but the difference was not significant.

\section{DISCUSSION}

Indomethacin is known to inhibit the synthesis of $\mathrm{PGs}$ in vivo and in vitro (Vane, 1971; Sorrentino, Capasso \& DiRosa, 1972). A significant reduction in PGF content was observed in the uterine tissue of mice $6 \mathrm{hr}$ after a single subcutaneous injection of $200 \mu \mathrm{g}$ indomethacin (Saksena, Lau \& Shaikh, 1974; Lau, Saksena \& Chang, 1974b). Administration of indomethacin to male rats in the present study resulted in a significant reduction in plasma PGF concentration and an apparent decrease in plasma PGE concentration, suggesting that the synthesis of PGs must have diminished.

The results of this study demonstrate that chronic treatment with indomethacin decreases plasma $\mathrm{LH}$ and testosterone levels in male rats. Administration of $\mathrm{PGF}_{2 \alpha}$ was shown to stimulate the release of $\mathrm{LH}$ in the rat and hamster (Saksena, Lau \& Chang, 1974) and in the ewe (Carlson, Barcikowski \& McCracken, 1973). Treatment with inhibitors of PG synthesis, indomethacin or aspirin, or with antiserum to PG was reported to block ovulation in rats, rabbits and mice (Armstrong \& Grinwich, 1972; Orczyk \& Behrman, 1972; Tsafriri, Lindner, Zor \& Lamprecht, 1972; O'Grady, Galdwell, Auletta \& Speroff, 1972; Lau et al., 1974a; Saksena, Lau \& Shaikh, 1974), possibly implicating an interference with the release of the ovulatory quota of LH. These reports and the present results suggest that PGs may normally be involved in the control of LH release, and that the reduced plasma LH levels in male rats treated with indomethacin were brought about by decrease in PG synthesis. The concentration of testosterone was reduced in the plasma of rats treated with indomethacin. This would account for the decreased weight of the seminal vesicles.

The decrease in plasma testosterone levels in rats injected with indomethacin was significant but apparently not sufficient to interfere with sperma- 
togenesis, maintenance of the prostatic weight, mating behaviour or fertility. This, however, does not mean that adequate testicular function is possible in the absence of endogenous PGs. Measurable amounts of PGE and PGF were detected in the plasma indicating that the synthesis of PGs was not completely suppressed by indomethacin. Failure to affect fertility was probably not due to infrequent administration of indomethacin (once a day), since no decrease in fertility was observed in male mice bearing subcutaneous implants of indomethacin in Silastic capsules (A. Bartke and S. K. Saksena, unpublished data). Maintenance of fertility could, however, be related to the incomplete suppression of PG synthesis.

In rats injected with indomethacin, plasma FSH levels were not significantly changed even though plasma LH levels were drastically reduced. The possibility of PG involvement in the control of the release of $\mathrm{LH}$, but not of $\mathrm{FSH}$, could be of relevance in the current dispute concerning the ability of a single hypothalamic releasing factor to account for regulation of both LH and FSH levels.

The relationship of the present findings to the suspected importance of PGs in the human semen is not clear. Rat semen was reported to contain few PGs (Ventura \& Freund, 1973) and no information is available on the effects of inhibitors of PG synthesis on the seminal PG concentration in rats and mice. In both these species, spermatozoa are transported through the cervix into the uterine lumen immediately following ejaculation, while in women, spermatozoa move actively through the cervical mucus and their migration may be affected by PGs (Eskin et al., 1973).

The discrepancy in plasma PGF levels between control rats used in this study and those described by Barcikowski et al. (1973) could be due to assays being performed in different laboratories, differences in the age of animals and between-assay variabilities, although, in each study, all PGF determinations were carried out in a single assay. Furthermore, tissue levels of PGF in the male reproductive system of rats and mice were observed to differ considerably in batches of animals of the same age and weight, killed on different occasions (A. Bartke and S. Koerner, unpublished data).

\section{AGKNOWLEDGMENTS}

We acknowledge with gratitude the gift of indomethacin from Merck, Sharpe and Dohme. Our thanks are due to Dr W. Stylos for PG antisera; Dr B. V. Galdwell for testosterone antiserum; Dr G. D. Niswender and Dr A. R. Midgley for LH antiserum; Dr L. E. Reichert, Jr for LH standards; Miss Carol Roberson for carrying out LH determination and Mrs Virginia Kelleher for typing the manuscript. This study was supported in part by the Ford Foundation (M.C.C.) and by a Research Career Development Award No. 5 KO4.HD-70369 (A.B.).

\section{REFERENGES}

Armstrong, D. T. \& Grinwich, D. L. (1972) Blockade of spontaneous and LH-induced ovulation in rats by indomethacin, an inhibitor of prostaglandin biosynthesis. Prostaglandins, 1, 21-28.

Barcikowski, B., Saksena, S. K. \& Bartke, A. (1973) Androgenic regulation of plasma prostaglandin $\mathrm{F}$ levels in the rat. $\mathcal{F}$. Reprod. Fert. 35, 549-551. 
Bartke, A., Musto, N., Caldwell, B. V. \& Behrman, H. R. (1973) Effects of a cholesterol esterase inhibitor and of prostaglandin $F_{2 \alpha}$ on testis cholesterol and on plasma testosterone in mice. Prostaglandins, 3, 97-104.

Bartke, A., Steele, R. E., Musto, N. \& Galdweld, B. V. (1973) Fluctuations in plasma testosterone levels in adult male rats and mice. Endocrinology, 92, 1223-1228.

Brummer, H. C. \& Gillespie, A. (1972) Seminal prostaglandins and fertility. Clin. Endocr. 1, $363-368$.

Byodeman, M., Fredricsson, B., Svanbörg, K. \& Samuglsson, B. (1970) The relation between fertility and prostaglandin content of seminal fluid in man. Fert. Steril. 21, 622-629.

Carlson, J. G., Barcikowski, B. \& McGracken, J. A. (1973) Prostaglandin $F_{2 \alpha}$ and the release of LH in sheep. 7. Reprod. Fert, 34, 357-361.

Carpenter, M. P., Manning, L. \& Wiseman, B. (1971) Prostaglandin synthesis in rat testis. Fedn Proc. Fedn Am. Socs exp. Biol. 30, 1081, Abstr.

Ericsson, R. J. (1973) Prostaglandins $\left(\mathbf{E}_{1}\right.$ and $\left.\mathbf{E}_{2}\right)$ and reproduction in the male rat. Adv. Biosci. 9, 737-742.

Eskin, B. A., Azarbal, S., Sepic, R. \& Slate, W. G. (1973) In vitro responses of spermatozoa-cervical mucus system treated with prostaglandin $\left(\mathrm{F}_{2_{\alpha}}\right)$. Obstet. Gynec., N.Y. 41, 436-439.

Gay, V. L., Niswender, G. D., Midaley, A. R. \& Reichert, L. E., JR (1970) Radioimmunoassay for rat FSH with antiserum to human FSH and radioiodinated rat FSH. Fedn Proc. Fedn Am. Socs exp. Biol. 29, 439, Abstr.

Hargrove, J. L., Johnson, J. M. \& Ellis, L. G. (1971) Prostaglandin E 1 induced inhibition of rabbit testicular contractions in vitro. Proc. Soc. exp. Biol. Med. 136, 958-961.

Lau, I. F., Saksena, S. K. \& Ghang, M. G. (1974a) Prostaglandins F and ovulation. F. Reprod. Fert. 40, 467-469.

Lau, I. F., Saksena, S. K. \& Ghang, M. G. (1974b) Prostaglandin F in the uterine horns of mice with intrauterine devices. 7. Reprod. Fert. 37, 429-432.

Lubicz-Nawrocki, G. M., Saksena, S. K. \& Ghang, M. G. (1973) The effect of prostaglandin $\mathrm{E}_{1}$ and $F_{2 \alpha}$ on the fertilizing ability of hamster spermatozoa. $\mathcal{F}$. Reprod. Fert. 35, 557-559.

Niswender, G. D., Midoley, A. R., Monroe, S. E. \& Reichert, L. E., Jr (1968) Radioimmunoassay for rat luteinizing hormone with anti-ovine $\mathrm{LH}$ serum and ovine LH- ${ }^{131}$ I. Proc. Soc. exp. Biol. Med. 128, 807-811.

O'Grady, J. P., Caldwell, B. V., Auletta, F. J. \& Speroff, L. (1972) The effects of an inhibitor of prostaglandin synthesis (indomethacin) on ovulation, pregnancy and pseudopregnancy in the rabbit. Prostaglandins, 1, 97-100.

Orczyx, G. P. \& Behrman, H. R. (1972) Ovulation blockade by aspirin or indomethacin-in vivo evidence for a role of prostaglandin in gonadotropin secretion. Prostaglandins, 1, 3-20.

Saksena, S. K., El Safoury, S. \& Bartke, A. (1973) Prostaglandin $\mathbf{E}_{2}$ and $\mathbf{F}_{\mathbf{2}_{\alpha}}$ decrease plasma testosterone levels in male rats. Prostaglandins, 4, 235-242.

Saksena, S. K., Lau, I. F. \& Bartxe, A. (1974) Prostaglandin $A_{1}$ and $A_{2}$ decrease testosterone levels in mice and rats. Endocrinology, 95, 311-314.

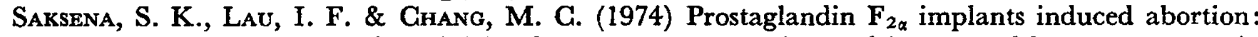
effect on progestin and luteinizing hormone concentration and its reversal by progesterone in rabbits, rats and hamsters. Fert. Steril. (in press).

Saksena, S. K., Lad, I. F. \& Shaikh, A. A. (1974) Cyclic changes in the uterine tissue content of Fprostaglandins and the role of prostaglandins in ovulation in mice. Fert. Steril. 25, 636-643.

Saksena, S. K., Watson, D., Lau, I. F. \& Shaikh, A. A. (1974) Peripheral plasma levels of E and F series prostaglandins during pseudopregnancy in the rat. Prostaglandins, 5, 557-565.

Sorrentino, L., Gapasso, F. \& DiRosa, M. (1972) Indomethacin and prostaglandins. Eur. 7. Pharmacol. 17, 306-308.

Stylos, W. A., Burstein, S., Rivetz, B., Gunsalus, P. \& Skarnes, R. G. (1972) The production of anti-F prostaglandin serum and its use in radioimmunoassay. Intra. Sci. Chem. Rep. 6, 67.

Stylos, W. A., Howard, L., Ritzi, E. M. \& Skarnes, R. G. (1974) The preparation and characterization of $\mathrm{PGE}_{1}$ antisera. Prostaglandins, 6, 1-13.

TAN, W. C. \& PrivetT, O. S. (1972) Analysis of prostaglandins in rat vesicular glands. Lipids, 7 $622-624$.

Tsafriri, A., Lindner, H. R., Zor, U. \& Lamprecht, S. A. (1972) Physiological role of prostaglandins in the induction of ovulation. Prostaglandins, 2, 1-10.

VANE, J. R. (1971) Inhibition of prostaglandin synthesis as a mechanism of action for aspirin-like drugs. Nature, New Biol. 231, 232-235.

Ventura, W. P. \& Freund, M. (1973) Evidence for a new class of uterine stimulants in rat semen and male accessory gland secretions. F. Reprod. Fert. 33, 507-511. 